\title{
Heavy Metals Determination and Assessment in a Petroleum Impacted River in the Niger Delta Region of Nigeria
}

\section{Hilary I Owamah*}

Department of Civil Engineering, Landmark University, P.M.B.1001, Omuaran, Kwara State, Nigeria

\begin{abstract}
The concentrations of heavy metals $(\mathrm{mg} / \mathrm{g}) \mathrm{Pb}, \mathrm{Ni}, \mathrm{Cu}, \mathrm{Cr}, \mathrm{Fe}, \mathrm{Co}, \mathrm{Cd}$, and $\mathrm{Hg}$ in the water and sediments of river ljana Warri, were determined in order to assess the impact of petroleum-processing activities on the river and the surrounding environment. The data showed that the levels of these metals ranged between 0.15-1.18 and 0.10-0.48 in sediment and water respectively. The heavy metals concentrations reported for the water have an abundance trend in the order of $\mathrm{Pb}>\mathrm{Fe}>\mathrm{Ni}>\mathrm{Cr}>\mathrm{Cu}>\mathrm{Co}>\mathrm{Cd}>\mathrm{Hg}$, while those of the sediments are in the order of $\mathrm{Pb}>\mathrm{Fe}>\mathrm{Cr}>\mathrm{Ni}>\mathrm{Cu}>\mathrm{Cd}>\mathrm{Hg}>\mathrm{Co}$. The control analysis was carried out in a non- oil polluted river (Ikpoba River) and the values served as base line values for the study.
\end{abstract}

Keywords: Heavy metals; Oil pollution; Environment; Sediment accumulation

\section{Introduction}

The high toxic and persistent nature of heavy metals in the environment has made heavy metals priority pollutants. For good environmental management an understanding of the changing concentration and distribution of heavy metals and their compounds in various compartments of the environment is of the essence. Several workers have investigated the concentration of heavy metals in the coastal rivers with Atlantic tidal effect in Nigeria. Egborge [1] related the heavy metal pollution of the Warri River to industrialization of Warri Town. Edema [2] investigated the heavy metal contents of the shellfishes of the Warri River catchments. Ndiokwere [3] investigated the heavy metal content of the sediments, algae and the Nigerian coastal waters. Ntekim et al. [4] reported on the distribution of trace metals in the sediments of the Calabar River, while Oluwande et al. [5] reported generally on the pollution levels in some Nigerian rivers. Adati [6], in his study showed that the annual oil spillage has significantly decreased but the annual oil spillage incidences are increasing.

Nigeria crude oils were studied and shown to contain relatively high concentrations of some heavy metals, $\mathrm{Fe}, \mathrm{Zn}, \mathrm{Cu}, \mathrm{Pb}$ and $\mathrm{Hg}$ [7].The indiscriminate discharge of effluents by the petroleum companies into the environment constitutes one of the main factors of degradation of the aquatic and terrestrial ecosystem located near major urban centers and contribute to the increase of the concentrations of heavy metals in these environment. The monitoring of heavy metals in the environment is fast becoming an essential aspect of pollution study [8-12].

The lack of natural elimination processes for metals aggravates the situation. As a result, metals shift from one compartment within the aquatic environment to another including the biota often with detrimental effects, through sufficient bioaccumulation. Food chain transfer also increases the toxicological risk in humans. [13,14]. As a result of adsorption and accumulation, the concentration of metals in bottom sediments is expected to be higher than in the water above and this sometimes can cause secondary pollution problems. This is why bottom sediments are repository of heavy metals. Heavy metals are of considerable environmental concern due to their toxicity and cumulative behavior [15]. Incidence of metallic poisoning arising from contamination of water, soil, food and feeding stuffs are well documented [16]. Toxicity from oil pollution can lead to respiratory illness, kidney disease, neurological diseases etc in humans [17].
Warri Refining and Petrochemical Company Limited, Ekpan Warri, generate effluent and discharge it into a natural receptor-River Ijana. Therefore it is important to monitor pollution limits of heavy metals in the aquatic ecosystem carefully, so that approximate measure of the potential hazards can be attained. These measures should give an estimation of the type of effects that could be expected after exposure to heavy metals. Thus, the intent of this research was to obtain information on the concentration and distribution of heavy metals in River Ijana as a result of petroleum impact on it.

Warri is in Delta State, which is part of the Niger Delta region of Nigeria. The study area (River Ijana) is located within longitude $5.540 \mathrm{E}$ and 5.70W and latitude $5.310 \mathrm{~N}$ and 5.60S.The activities along the river course include auto-mechanic workshops, petroleum refinery and services, bathing, fishing and swimming.

The river is unidirectional in the upper reach and tidal in the lower reach. Its upstream reach is fresh water with dense forest vegetation. The downstream reach is however brackish and consist of Mangrove. The area experienced tropical humidity of the semi-hot equatorial type-with a mean annual rainfall of about $3000 \mathrm{~mm}$.The wet season period stretches from April to October each year and however with occasional precipitation in the dry season month of November-March. The study area plays host to one of the three refineries in the country and many other petrochemical subsidiary industries. Gas flaring occurs routinely at the refinery and effluents discharged into the immediate environment.

\section{Materials and Methods}

Three sampling sites along the river course were utilized for data

*Corresponding author: Hilary I. Owamah, Department of Civil Engineering, Landmark University, Omuaran, Kwara State, Nigeria, Tel: +2348035705814; E-mail: dahilla222@yahoo.com

Received October 26, 2012; Accepted January 15, 2013; Published January 17 2013

Citation: Owamah HI (2013) Heavy Metals Determination and Assessment in a Petroleum Impacted River in the Niger Delta Region of Nigeria. J Pet Environ Biotechnol 4: 135. doi:10.4172/2157-7463.1000135

Copyright: (c) 2013 Owamah HI. This is an open-access article distributed unde the terms of the Creative Commons Attribution License, which permits unrestricted use, distribution, and reproduction in any medium, provided the original author and source are credited. 
Citation: Owamah HI (2013) Heavy Metals Determination and Assessment in a Petroleum Impacted River in the Niger Delta Region of Nigeria. J Pet Environ Biotechnol 4: 135. doi:10.4172/2157-7463.1000135

Page 2 of 4

collection. Each site is about $2 \frac{1}{2} \mathrm{~km}$ from the other. The respective sampling sites were represented as 1,2 and 3 while the respective river water and bed sediment samples from these sites were represented as $\mathrm{RW}_{1}, \mathrm{RW}_{2}, \mathrm{RW}_{3}$ and $\mathrm{BS}_{1}, \mathrm{BS}_{2}$ and $\mathrm{BS}_{3}$. These sites were so chosen because there the strategic points where major activities in the river take place. There are also the reception points of the industrial effluents. Sampling was done three months each for the wet and dry season of the year.

Sampling was done in the months of December, January and February to represent dry season and the months of May, June and July to represent rainy season. In each sampling site along the course of the river, a composite water samples was taken at a depth of ten centimeters to obtain a true sampling representative of each sampling site. The water was collected in opposite direction to the flow of the river with a well labelled polyethene container that had earlier been rinsed with acidified water. Immediately after collection, the samples were carefully stoppered to avoid contact with air. The water samples were taken to the laboratory and stored at $4^{\circ} \mathrm{C}$ in a refrigerator prior to chemical analysis. The sediment samples were pre-treated before final analysis. Same was done to the water and sediments from Ikpoba River which served as the control river, a non oil-polluted river.

The samples were analyzed using Varian spectra AA10 Atomic Absorption, Spectrophotometer with an air/acetylene flame. With the exception of $\mathrm{Hg}$, which was determined by a modification of the AAS, total mercury was determined by a cold-vapour technique after wet washing. The total mercury was reduced to metallic form when it could be volatilized by aeration and measured by flameless AAS The concentration of $\mathrm{Pb}, \mathrm{Ni}, \mathrm{Cu}, \mathrm{Cr}, \mathrm{Fe}, \mathrm{Co}, \mathrm{Cd}$, and $\mathrm{Hg}$ in water and sediments collected from petroleum-impacted river (Ijana river) in the Niger-Delta area of Nigeria and the non-petroleum impacted river (Ikpoba river) were determined and shown in Tables 1-4.

\section{Results and Discussion}

Analysis of variance was performed on all data and the completely Randomized Block Design (CRBD) was used to compare the means. Completely randomized block design was adopted to allow for the

\begin{tabular}{|c|c|c|c|c|c|c|}
\hline \multirow{2}{*}{ Parameter mg/l } & \multicolumn{2}{|c|}{ Point 1 } & \multicolumn{2}{c|}{ Point 2 } & \multicolumn{2}{c|}{ Point 3 } \\
\cline { 2 - 7 } & Water Mean \pm SD & Sediment Mean \pm SD & Water Mean \pm SD & Sediment Mean \pm SD & Water Mean \pm SD & Sediment Mean \pm SD \\
\hline $\mathrm{Fe}$ & $1.28 \pm 0.002$ & $3.51 \pm 0.001$ & $1.56 \pm 0.002$ & $3.58 \pm 0.002$ & $1.47 \pm 0.002$ & $2.61 \pm 0.02$ \\
\hline $\mathrm{Cr}$ & $0.57 . \pm 0.001$ & $0.79 \pm 0.01$ & $0.44 \pm 0.001$ & $0.99 \pm 0.003$ & $0.33 \pm 0.001$ & $0.95 \pm 0.001$ \\
\hline $\mathrm{Ni}$ & $0.48 \pm 0.002$ & $1.27 \pm 0.001$ & $0.49 \pm 0.001$ & $1.1 \pm 0.003$ & $0.68 \pm 0.001$ & $1.22 \pm 0.001$ \\
\hline $\mathrm{Pb}$ & $0.99 \pm 0.002$ & $1.22 \pm 0.001$ & $0.72 \pm 0.001$ & $1.36 \pm 0.001$ & $0.82 \pm 0.002$ & $2.00 \pm 0.003$ \\
\hline $\mathrm{Cu}$ & $0.55 \pm 0.001$ & $0.84 \pm 0.001$ & $0.30 \pm 0.001$ & $0.96 \pm 0.001$ & $0.37 \pm 0.001$ & $1.22 \pm 0.001$ \\
\hline $\mathrm{Cd}$ & $0.50 \pm 0.001$ & $0.56 \pm 0.001$ & $0.49 \pm 0.002$ & $0.68 \pm 0.001$ & $0.52 \pm 0.001$ & $0.74 \pm 0.002$ \\
\hline $\mathrm{Co}$ & $0.13 \pm 0.001$ & $0.62 \pm 0.002$ & $0.12 \pm 0.002$ & $0.64 \pm 0.001$ & $0.14 \pm 0.001$ & $0.59 \pm 0.002$ \\
\hline $\mathrm{Hg}$ & $0.12 \pm 0.001$ & $0.26 \pm 0.001$ & $0.12 \pm 0.001$ & $0.32 \pm 0.001$ & $0.13 \pm 0.001$ & $0.34 \pm 0.001$ \\
\hline
\end{tabular}

Results are expressed as means \pm SEM of six determinations; concentrations of the heavy metals is in $(\mathrm{mg} / \mathrm{g})$

Table 1: Concentration of selected heavy metals in water and sediments from petroleum imparted river (Warri River) in the Niger Delta, Nigeria during the dry season.

\begin{tabular}{|c|c|c|c|c|c|c|}
\hline \multirow{2}{*}{ Parameter mg/l } & \multicolumn{2}{|c|}{ Point 1} & \multicolumn{2}{|c|}{ Point 2} & \multicolumn{2}{|c|}{ Point 3} \\
\hline & Water Mean \pm SD & Sediment Mean \pm SD & Water Mean \pm SD & Sediment Mean \pm SD & Water Mean \pm SD & Sediment Mean \pm SD \\
\hline $\mathrm{Fe}$ & $1.41 \pm 0.03$ & $3.11 \pm 0.006$ & $1.36 \pm 0.002$ & $2.38 \pm 0.002$ & $1.37 \pm 0.002$ & $2.31 \pm 0.02$ \\
\hline $\mathrm{Cr}$ & $0.45 \pm 0.001$ & $0.68 \pm 0.01$ & $0.34 \pm 0.001$ & $0.89 \pm 0.001$ & $0.33 \pm 0.001$ & $0.85 \pm 0.001$ \\
\hline $\mathrm{Ni}$ & $0.38 \pm 0.002$ & $1.19 \pm 0.001$ & $0.47 \pm 0.001$ & $0.91 \pm 0.001$ & $0.54 \pm 0.001$ & $1.16 \pm 0.001$ \\
\hline $\mathrm{Pb}$ & $0.95 \pm 0.002$ & $1.18 \pm 0.001$ & $0.92 \pm 0.001$ & $1.15 \pm 0.001$ & $0.78 \pm 0.002$ & $1.77 \pm 0.004$ \\
\hline $\mathrm{Cu}$ & $0.42 \pm 0.001$ & $0.73 \pm 0.001$ & $0.30 \pm 0.001$ & $0.86 \pm 0.002$ & $0.28 \pm 0.001$ & $1.20 \pm 0.001$ \\
\hline $\mathrm{Cd}$ & $0.30 \pm 0.001$ & $0.52 \pm 0.001$ & $0.39 \pm 0.002$ & $0.67 \pm 0.001$ & $0.22 \pm 0.001$ & $0.64 \pm 0.002$ \\
\hline $\mathrm{C}_{\mathrm{O}}$ & $0.11 \pm 0.001$ & $0.49 \pm 0.001$ & $0.13 \pm 0.001$ & $0.46 \pm 0.002$ & $0.12 \pm 0.001$ & $0.49 \pm 0.001$ \\
\hline $\mathrm{Hg}$ & $0.10 \pm 0.003$ & $0.22 \pm 0.003$ & $0.12 \pm 0.001$ & $0.3 \pm 0.002$ & $0.11 \pm 0.003$ & $0.26 \pm 0.001$ \\
\hline
\end{tabular}

Results are expressed as means \pm SEM of six determinations; concentrations of the heavy metals is in $(\mathrm{mg} / \mathrm{g})$

Table 2: Concentration of selected heavy metals in water and sediments from petroleum imparted river (Warri River) in the Niger Delta, Nigeria during the rainy season

\begin{tabular}{|c|c|c|c|c|c|c|}
\hline \multirow{2}{*}{ Parameter mg/l } & \multicolumn{2}{|c|}{ Point 1} & \multicolumn{2}{|c|}{ Point 2} & \multicolumn{2}{|c|}{ Point 3} \\
\hline & Water Mean \pm SD & Sediment Mean \pm SD & Water Mean \pm SD & Sediment Mean \pm SD & Water Mean \pm SD & Sediment Mean \pm SD \\
\hline $\mathrm{Fe}$ & $0.22 \pm 0.002$ & $0.30 \pm 0.001$ & $0.16 \pm 0.002$ & $0.38 \pm 0.002$ & $0.27 \pm 0.001$ & $0.28 \pm 0.002$ \\
\hline $\mathrm{Cr}$ & $0.17 \pm 0.001$ & $0.29 \pm 0.001$ & $0.15 \pm 0.01$ & $0.29 \pm 0.003$ & $0.16 \pm 0.001$ & $0.22 \pm 0.001$ \\
\hline $\mathrm{Ni}$ & $0.08 \pm 0.002$ & $0.09 \pm 0.001$ & $0.06 \pm 0.001$ & $0065 \pm 0.003$ & $0.04 \pm 0.001$ & $0.052 \pm 0.001$ \\
\hline $\mathrm{Pb}$ & $0.20 \pm 0.002$ & $0.22 \pm 0.001$ & $0.17 \pm 0.001$ & $0.26 \pm 0.001$ & $0.18 \pm 0.002$ & $0.19 \pm 0.003$ \\
\hline $\mathrm{Cu}$ & $0.11 \pm 0.01$ & $0.14 \pm 0.001$ & $0.10 \pm 0.001$ & $0.16 \pm 0.001$ & $0.07 \pm 0.001$ & $0.22 \pm 0.001$ \\
\hline $\mathrm{Cd}$ & $0.05 \pm 0.001$ & $0.06 \pm 0.001$ & $0.04 \pm 0.002$ & $0.06 \pm 0.001$ & $0.02 \pm 0.001$ & $0.04 \pm 0.002$ \\
\hline Co & $0.03 \pm 0.001$ & $0.02 \pm 0.002$ & $0.02 \pm 0.002$ & $0.04 \pm 0.001$ & $0.04 \pm 0.001$ & $0.06 \pm 0.002$ \\
\hline $\mathrm{Hg}$ & $0.02 \pm 0.001$ & $0.06 \pm 0.001$ & $0.02 \pm 0.001$ & $0.02 \pm 0.001$ & $0.03 \pm 0.001$ & $0.04 \pm 0.001$ \\
\hline
\end{tabular}

Results are expressed as means \pm SEM of six determinations; concentrations of the heavy metals is in $(\mathrm{mg} / \mathrm{g})$

Table 3: Concentration of selected heavy metals in water and sediments from non-petroleum imparted river (Ikpoba River) in the Niger Delta, Nigeria during the dry season. 


\begin{tabular}{|c|c|c|c|c|c|c|}
\hline \multirow{2}{*}{ Parameter mg/l } & \multicolumn{2}{|c|}{ Point 1} & \multicolumn{2}{|c|}{ Point 2} & \multicolumn{2}{|c|}{ Point 3} \\
\hline & Water Mean \pm SD & Sediment Mean \pm SD & Water Mean \pm SD & Sediment Mean \pm SD & Water Mean \pm SD & Sediment Mean \pm SD \\
\hline $\mathrm{Fe}$ & $0.12 \pm 0.002$ & $0.13 \pm 0.001$ & $0.12 \pm 0.002$ & $0.18 \pm 0.002$ & $0.11 \pm 0.001$ & $0.18 \pm 0.002$ \\
\hline $\mathrm{Cr}$ & $0.11 \pm 0.001$ & $0.19 \pm 0.001$ & $0.13 \pm 0.001$ & $0.19 \pm 0.003$ & $0.11 \pm 0.001$ & $0.12 \pm 0.001$ \\
\hline $\mathrm{Ni}$ & $0.06 \pm 0.002$ & $0.08 \pm 0.001$ & $0.04 \pm 0.001$ & $0.07 \pm 0.003$ & $0.02 \pm 0.001$ & $0.05 \pm 0.001$ \\
\hline $\mathrm{Pb}$ & $0.10 \pm 0.002$ & $0.20 \pm 0.001$ & $0.17 \pm 0.001$ & $0.23 \pm 0.001$ & $0.18 \pm 0.002$ & $0.16 \pm 0.003$ \\
\hline $\mathrm{Cu}$ & $0.01 \pm 0.001$ & $0.04 \pm 0.001$ & $0.01 \pm 0.001$ & $0.06 \pm 0.001$ & $0.02 \pm 0.001$ & $0.03 \pm 0.001$ \\
\hline $\mathrm{Cd}$ & $0.04 \pm 0.001$ & $0.06 \pm 0.001$ & $0.02 \pm 0.002$ & $0.04 \pm 0.001$ & $0.01 \pm 0.001$ & $0.03 \pm 0.002$ \\
\hline Co & $0.02 \pm 0.001$ & $0.03 \pm 0.002$ & $0.01 \pm 0.002$ & $0.05 \pm 0.001$ & $0.02 \pm 0.001$ & $0.05 \pm 0.002$ \\
\hline $\mathrm{Hg}$ & $0.01 \pm 0.001$ & $0.05 \pm 0.001$ & $0.01 \pm 0.001$ & $0.01 \pm 0.001$ & $0.03 \pm 0.001$ & $0.02 \pm 0.001$ \\
\hline
\end{tabular}

Results are expressed as means \pm SEM of six determinations; concentrations of the heavy metals is in $(\mathrm{mg} / \mathrm{g})$

Table 4: Concentration of selected heavy metals in water and sediments from non-petroleum imparted river (Ikpoba River) in the Niger Delta, Nigeria during the rainy season.

comparison of heavy metal concentration in sediment and water, as well as the difference in the level of the heavy metals in the polluted and non- polluted rivers.

Tables 1 and 2 shows the concentrations of the heavy metals in sediments and water during the dry and rainy season respectively, for samples collected from Ijana River. Generally, the levels of these heavy metals were significantly $(\mathrm{P}<0.05)$ higher in sediments relative to water, indicating that bottom sediments are repository of heavy metals.

Tables 3 and 4 show the levels of these metals in water and sediments collected from Ikpoba River, a non-petroleum impacted river during the dry and rainy season. Again, the levels of these heavy metals were significantly $(P<0.05)$ higher in sediments relative to the water. There was significant $(\mathrm{P}<0.05)$ difference in the level of these heavy metals in water and sediments collected from the petroleumimpacted river relative to the non petroleum-impacted river. The heavy metals were much higher in the petroleum in both water and sediments of the petroleum impacted river than does the river with no petroleum impact. From Tables 1-4, the heavy metal concentrations at sampling station 2, appear to be relatively higher than the two other sampling stations (1 and 3), suggesting the presence of higher pollution activities within the surrounding of sampling station 2.This calls for an urgent attention as more people live within sampling station 2 and usually use the river water for so many domestic purposes.

\section{Conclusion}

Crude-oil-induced bio-concentration of heavy metals in water and fishes in the Niger-Delta are well documented [18,19]. Edema [2] investigated the heavy metal contents of the shellfishes of the Warri River catchments. The result of this study showed a higher concentration of heavy metals in the petroleum-impacted river relative to the non-impacted river. This could be attributed to the intentional discharge of petroleum effluents into the environments as well as the re-occurring incidence of oil spillage [1].

The levels of heavy metals detected in the water were lower than that obtained for sediments in crude oil impacted sites (I, II and III), suggesting that the accumulation of heavy metals occur more in sediments, hence the bottom sediments are repository of heavy metals and possible sources of secondary pollution.

Comparatively, the levels of the heavy metals determined seem to be practically equal in both sediments and water from the nonpetroleum impacted river (Ikpoba River) with slight differences. However, the concentration of heavy metals from the non-impacted river is significantly $(\mathrm{P}<0.05)$ lower than value from the petroleum impacted river and this suggests that the higher concentrations of these heavy metals detected in the water and sediments from the petroleum impacted river rose due to exposure to effluents and oil spillages in the course of petroleum production and processing as well as the activities of several petrochemical industries in this area [1].

Analysis of variance shows that there is a significant difference in the individual heavy metal concentrations and there is also a significant difference in the level of these concentrations in the sediment and water samples collected from petroleum impacted river. The analysis of variance still shows that there is a much significant difference in the heavy metal concentrations between the petroleum impacted and the non-impacted river. There was no significant difference in the level of these heavy metal concentrations on the sediment and water samples collected from non-petroleum impacted river, indicating that in the absence of anthropogenic pollution, the levels of heavy metal concentrations in water and sediments of a river are fairly the same.

The levels of heavy metals, namely cadmium, chromium, copper, iron, nickel and lead analyzed in the River Ijana were generally, above W.H.O. standards recommended for surface waters. This is an indication of pollution.

Generally, the results of this study show that the level of $\mathrm{Pb}$ is the highest among the heavy metals determined and this portends danger to the inhabitants of this area (Warri and its environs), who depend on the surface water in the region for domestic uses. This is because earlier studies had reported on the toxic effect of atmospheric lead on humans [20]. The higher records of metals during the dry season could be attributed to low influx of fresh water and evaporation resulting in the concentration of materials in the river. A higher concentration of lead has also been found in soil and groundwater impacted with petroleum exploration and production activities [21].

The levels of heavy metals determined in this study may represent an early stage in the accumulation of heavy metals in ecological materials in the immediate environment of the petroleum-impacted river of the Niger Delta area of Nigeria. It is, therefore, recommended that appropriate measures be put in place by government and petroleum companies to check the discharge of waste effluent into the environment. Lastly, the monitoring of heavy metals in rivers and ecological materials should be a continuous process.

\section{References}

1. Egborge AB (1991) Industrialization and Heavy Metal Pollution in Warri River $32^{\text {nd }}$ inaugural lecture. University of Benin, Benin-City, Nigeria, pp. 22.

2. Edema CU (1993) Heavy metals in shell fishes of Warri River catchment's area PhD Thesis, University of Benin, Benin City, Nigeria.

3. Ndiokwere CL (1984) An investigation of the heavy metal content of sediments 
Citation: Owamah HI (2013) Heavy Metals Determination and Assessment in a Petroleum Impacted River in the Niger Delta Region of Nigeria. J Pet Environ Biotechnol 4: 135. doi:10.4172/2157-7463.1000135

Page 4 of 4

and algae from the River Niger and Nigerian Atlantic coastal waters. Environmental Pollution Series B, Chemical and Physical 7: 247-254.

4. Ntekim EEU, Ekwere SJ, Ukpong EE (1993) Heavy metal distribution in sediments from Calabar River, southeastern Nigeria. Environmental Geology 21: $237-241$

5. Oluwande PA, Sridhar MKC, Bammeke AO, Okubadejo AO (1983) Pollution levels in some Nigerian Rivers. Water Research 17: 957-963.

6. Kadafa AA (2012) Oil Exploration and Spillage in the Niger Delta of Nigeria. Civil and Environmental Research 2.

7. Kakulu SE (1985) Heavy metals in Niger Delta: Impact of the petroleum industry on the base line level. PhD thesis, Department of Chemistry, University of Ibadan, Nigeria.

8. Kakulu SE, Osibanjo O, Ajayi SO (1987) Trace metal content of fish and shellfishes of the Niger Delta area of Nigeria. Environmental International 13: 247-251.

9. Omgbu JA (1992) The distribution of $\mathrm{Fe}, \mathrm{Hg}, \mathrm{Zn}, \mathrm{Cd}, \mathrm{Cu}$, and $\mathrm{Pb}$ in soil of Forcados terminal and its environs. M.sc. Theses, Department of Chemistry, University of Port-Harcourt, Nigeria.

10. Ataikuiru $\mathrm{H}$ (1997) The distribution of $\mathrm{Fe}, \mathrm{Cd}, \mathrm{Ni}, \mathrm{Pb}$ and $\mathrm{Hg}$ in soils of Ovwian/ Aladja, Nigeria. Bulletin of the Science Association of Nigeria 21: 35-37.

11. Egboh SHO, Nwajei GE, Adaikpoh EO (2000) Selected heavy metals concentration in sediments from major roads and gutters in Warri, Delta State of Nigeria. Nigerian Journal of Science and Environment 2: 105-111.

12. Osakwe SA, Otuya BO, Adaikpoh EO (2003) Determination of Pb, Cu, Ni, Fe, and $\mathrm{Hg}$ in the soils of Okpai Delta State, Nigeria. Nigerian Journal of Science and Environment 3: 45-49.

13. Rainbow PS (1985) The biology of heavy metals in the sea. International Journal of Environmental Studies 25: 195- 211.

14. Mason CF (1991) Biology of freshwater pollution. Prentice Hall, New York, USA: 387.

15. Purves D (1985) Trace-element contamination of the environment. Amsterdam, Netherlands. Elsevier: 243.

16. Ezeonu E (2004) Chemistry in Nigeria: A national magazine of chemical society of Nigeria. 2: 17-20.

17. Ndubuisi OL, Asia IO (2007) Environmental Pollution in Oil Producing Areas of the Niger Delta Basin, Nigeria: Empirical Assessment of Trends and People's Perception. Environmental Research Journal 1: 18-26.

18. Ezemonye LIN (1992) Heavy metals concentration in waters, sediments and selected fish of Warri River and its tributaries. PhD theses, University of Benin Nigeria.

19. Agada EGO (1994) Heavy metals concentration in fish fauna of Warri River and its tributaries. PhD Theses, University of Benin, Nigeria.

20. Pfeifer WC, Lacerda LD, Fiszman M, Lima NRW (1985) Metais pesados no pescado da Baia de Sepetiba, Estado do Rio de Janeiro, Brasil', Ci. e Cult. Ciencia e Cultura 37: 297-302.

21. Asia IO, Jegede SI, Jegede DA, Ize-lyamu OK, Akpasubi EB (2007) The effects of petroleum exploration and production operations on the heavy metals contents of soil and groundwater in the Niger Delta. International Journal of physical sciences 2: 271-275. 